\title{
Implementasi Model Perhitungan Perkiraan Total Fertility Rate (TFR) Berdasarkan Efektifitas Penggunaan Alat Kontrasepsi di Provinsi Jawa Barat
}

\author{
Gani Gunawan, Eti Kurniati, Icih Sukarsih \\ Program Studi Matematika, FMIPA, Universitas Islam Bandung \\ ggani9905@unisba.ac.id, eti@unisba.ac.id, sukarsih@unisba.ac.id
}

\begin{abstract}
Abstrak. Perhitungan jumlah penduduk dapat dilakukan secara langsung melalui suatu sensus penduduk. Salah satu faktor yang dapat mempengaruhi jumlah penduduk pada suatu wilayah adalah tingkat kelahiran atau angka fertilitas. Namun hasil pendataan yang dilakukan pada umumnya hanya memberikan informasi jumlah penduduk yang hidup pada saat sensus diadakan dan tidak mencatat secara lengkap jumlah bayi lahir hidup yang kemudian meninggal pada waktu sensus. Hal tersebut menyebabkan perhitungan angka fertilitas secara langsung tidak mungkin dilakukan, sehingga diperlukan suatu metode Matematika yang secara tak langsung dapat digunakan untuk menghitung angka fertilitas di suatu wilayah. Dalam makalah ini akan diperlihatkan suatu cara perhitungan kelahiran atau fertilitas secara tidak langsung, dimana cara ini dapat menentukan angka kelahiran tercegah sebagai indikator keberhasilan pengendalian jumlah penduduk melalui program Keluarga Berencana (KB), sehingga melalui perhitungan ini dapat ditentukan angka fertilitas total yang didasarkan pada efektifitas penggunaan alat kontrasepsi.
\end{abstract}

Kata Kunci : keluarga berencana $(K B)$, total fertility rate $(T F R)$, crude birth rate $(C B R)$

\begin{abstract}
Implementation of the Calculation Model for Estimated Total Fertility Rate (TFR) Based on the Effectiveness Use of Contraception in West Java Province) The calculation of the population can be done directly through a population census. One factor that can affect the population in a region is the birth rate or fertility rate. However, the results of data collection carried out, in general only provide information on the number of people living at the time the census is held, and not complete records of the number of live-born babies who later died during the census. This has made it impossible to calculate the fertility rate directly, so a Mathematical method is needed that can indirectly be used to calculate the fertility rate in an area. This paper will show a method of calculating birth or fertility indirectly, where this method can determine the preventable birth rate as an indicator of the success of controlling population through Family Planning (KB) programs, so that through this calculation can be determined the total fertility rate based on effectiveness use of contraceptives.
\end{abstract}

Keywords : family planning $(K B)$, total fertility rate $(T F R)$, crude birth rate $(C B R)$

\section{Pendahuluan}

Salah satu faktor yang mempengaruhi pertumbuhan penduduk adalah tingkat kelahiran atau fertilitas selain faktor mortalitas dan migrasi. Faktor fertilitas secara umum berkorelasi positif terhadap laju pertumbuhan penduduk. Oleh karena itu, pengendalian jumlah penduduk yang terkait faktor fertilitas dapat dilakukan melalui gerakan program Keluarga Berencana (KB). Secara umum dalam kurun waktu tertentu angka fertilitas dari suatu wilayah cenderung bersifat fluktuatif. Hal ini menunjukan bahwa banyak faktor yang mempengaruhi pengendalian angka kelahiran atau fertilitas melalui program Keluarga Berencana (KB). Meskipun pemakaian alat kontrasepsi bukan merupakan satu-satunya faktor yang secara langsung berpengaruh, namun diyakini bahwa faktor ini memberikan kontribusi terbesar terhadap penurunan fertilitas (Subrata, 1995). Hasil Survey Demografi dan Kesehatan Indonesia (SDKI) tahun 1994 menunjukan bahwa 96\% wanita bestatus 
kawin telah mengetahui cara dalam penggunaan alat kontrasepsi modern. Bertambahnya pengetahuan wanita tentang cara KB diikuti dengan kenaikan Pasangan Usia Subur (PUS) yang pernah pakai salah satu cara atau alat KB modern, menurut catatan Badan Koordinasi Keluarga Nasional (BKKBN), angka persentase PUS yang pernah memakai salah satu cara atau alat kontrasepsi modern sejak dari tahun 1987 sampai dengan saat ini selalu terjadi peningkatan.

Dalam makalah ini akan diperlihatkan suatu cara untuk menentukan angka kelahiran pada suatu wilayah secara tidak langsung melalui model matematika. Perkiraan angka kelahiran dengan cara ini relatif sangat sederhana, dan dalam perhitungannya dapat dilakukan secara manual. Secara umum dapat dikatakan bahwa melalui model ini, terumuskan suatu metoda matematik untuk dapat menunjukan adanya hubungan negatif antara pencapaian peserta KB dengan angka kelahiran kasar (Crude Birth Rate -CBR) dan angka kelahiran total (Total Fertility Rate-TFR). Selama ini perhitungan TFR selalu berdasarkan pada jumlah penduduk sehingga tidak dapat melihat keefektifan penggunaan alat kontrasepsi dalam pengendalian jumlah penduduk melalaui program KB. Melalui perhitungan ini akan dapat dihitung perkiraan proyeksi TFR dan efektifitas alat kontrasepsi, sehingga perhitungan yang diperoleh untuk TFR tidak hanya didasarkan jumlah penduduk namun juga didasarkan pada efektifitas pengguanaan alat kontrasepsi. Selain itu, untuk keperluan perhitungannya dalam makalah ini dipergunakan asumsi laju pertumbuhan Pasangan Usia Subur (PUS) yang selama ini selalu diasumsikan bersifat eksponensial. Padahal menurut Azizah $\mathrm{N}$ dan Gunawan G (2015) laju pertumbuhan PUS dapat saja bersifat logistik.

\section{Kajian Pustaka}

Estimasi demografi terdiri dari upaya mengukur nilai dasar parameter demografi seperti tingkat kelahiran dan tingkat kematian dalam kondisi data yang kurang sempurna. Parameter dasar ini mengindikasikan cara sebuah penduduk akan berkembang sepanjang waktu baik dari segi jumlah maupun struktur umur.

Pada dasarnya estimasi fertilitas dapat dilakukan memakai dua jenis data yaitu yang langsung berhubungan dengan peristiwa kelahiran (cara langsung, direct method) dan yang secara tidak langsung berkaitan dengan kejadian kelahiran tetapi dengan teknik tertentu dapat dikonversikan menjadi ukuran fertilitas (Mundiharno, 1998).

Fertilitas merupakan performan reproduksi aktual dari seorang wanita atau sekelompok individu, yang pada umumnya dikenakan pada seorang wanita atau sekelompok wanita (Rusli, 1995). Sedangkan menurut Lucas (1984) fertilitas adalah hasil reproduksi yang nyata dari seorang atau sekelompok wanita berdasarkan banyaknya bayi dilahirkan hidup.

Dalam ilmu demografi terdapat beberapa ukuran fertilitas, diantaranya Crude Birth Rate (CBR) atau angka kelahiran kasar, merupakan ukuran kelahiran yang sering digunakan. Dalam hal ini angka kelahiran kasar adalah jumlah kelahiran pada suatu tahun tertentu dibagi jumlah penduduk pada pertengahan tahun yang sama (Brown, 1997). Secara matematik dapat dirumuskan oleh

$$
C B R=\frac{B(t)}{P(t)}
$$

Di mana $B(t)$ merupakan jumlah kelahiran hidup pada waktu $t$ dan $P(t)$ merupakan jumlah penduduk pada waktu $t$.

Pada $C B R$ ini jumlah kelahiran tidak dikaitkan secara langsung dengan penduduk wanita, melainkan dikaitkan dengan jumlah penduduk secara keseluruhan (Ambarpratiwi E, 2001). Ukuran fertilitas yang lain untuk keperluan perhitungan tak langsung adalah rasio anak-wanita (Child Woman Ratio, CWR) merupakan ukuran fertilitas yang diperoleh dari sensus penduduk, $C W R$ ini dinyatakan dengan rasio jumlah anak umur $[c, d]$ tahun terhadap wanita umur reproduksi $[h, k]$ tahun dinyatakan dalam rumus 


$$
C W R=\frac{P_{[c, d]}}{P_{[h, k]}^{w}}
$$

Dengan $P_{[c, d]}$ merupakan jumlah penduduk umur $[c, d]$ tahun dan $P_{[h, k]}^{w}$ merupakan jumlah penduduk wanita umur reproduksi $[h, k]$ tahun.

Ukuran fertilitas selanjutnya adalah Age Spesific Fertility Rate (ASFR) yang merupakan ukuran fertilitas pada wanita umur tertentu, dan faktanya menunjukkan bahwa jumlah kelahiran selama jangka waktu tertentu bervariasi menurut umur ibu. Secara matematis dirumuskan oleh

$$
\operatorname{ASFR}_{x}=\frac{B_{x}(t)}{P_{x}^{w}(t)}
$$

di mana $B_{x}(t)$ merupakan jumlah kelahiran hidup dari wanita usia $x$ pada waktu $t$ dan $P_{x}^{w}(t)$ merupakan jumlah penduduk wanita umur $x$ pada waktu $t$, atau dapat juga ditulis

$$
f_{x}^{t}=\frac{B_{x}(t)}{P_{x}^{w}(t)}
$$

dengan $f_{x}^{t}$ adalah tingkat fertilitas wanita umur $x$ pada waktu $t$. Total dari ukuran fertilitas ASFR tersebut dapat dinyatakan sebagai angka kelahiran total atau Total Fertility Rate (TFR), yaitu

$$
T F R=\sum_{x=h}^{k} f_{x}^{t}
$$

di mana $h$ dan $k$ merupakan batas bawah dan batas atas umur wanita reproduksi.

Menurut Rusli (1995), jika ukuran-ukuran fertilitas di atas tidak membedakan jenis kelamin bayi maka ukuran reproduksi hanya memperhatikan bayi wanita, hal ini karena dipandang bahwa bayi wanitalah yang secara langsung berkaitan dengan pergantian generasi. Dalam hal ini dikenal ukuran reproduksi Gross Reproduction Rate $(G R R)$. GRR ini menyatakan tingkat reproduksi kasar yang tidak memperhitungkan unsur kematian. Menurut Brown (1997) didefinisikan bahwa angka reproduksi kasar $(G R R)$ adalah rata-rata jumlah anak perempuan yang dilahirkan oleh seorang wanita selama masa reproduksinya, tanpa memperhitungkan kemungkinan anak perempuan yang dilahirkan meninggal sebelum mengakhiri masa reproduksinya, secara matematik dapat ditulis

$$
G R R=\sum_{x=h}^{k} f_{x}^{w, t}
$$

di mana $f_{x}^{w, t}$ merupakan tingkat fertilitas wanita umur $x$ terhadap bayi wanita (w) pada waktu $t$.

Menurut Sorvianti (2012), metoda pengukuran fertilitas secara tak langsung yang dapat digunakan untuk menghitung tingkat fertilitas berdasarkan pada konsep penduduk stabil adalah metoda Rele. Metoda ini digunakan untuk menduga GRR. Pada metoda ini nilai GRR diperoleh dari nilai Child Women Ratio (CWR) dan angka harapan hidup. 


\section{Metode Penelitian}

Data yang diperlukan untuk menghitung $G R R$ pada metoda ini diperoleh dengan menggunakan data sensus. Konsep perhitungan ukuran fertilitas di provinsi Jawa Barat didasarkan pada konsep penduduk stabil (Oktriani D, Gunawan G; 2015). Namun dari hasil penelusuran lebih lanjut, perhitungan perkiraan ukuran fertilitas dengan konsep penduduk stabil ini hanya didasarkan pada $G R R$ dan $C W R$. Dalam hal ini data yang digunakan untuk memperkirakan angka TFR hanya didasarkan pada jenis kelamin dan kelompok umur dengan memperhatikan angka harapan hidup pada saat itu. Sehingga proyeksi angka TFR sangat bergantung pada perkiraan data-data tersebut tidak memperhatikan pengaruh pemakaian alat kontrasepsi dan kriteria efektifitasnya. Sehingga ukuran keberhasilan pengendalian jumlah penduduk di suatu wilayah hanya dapat dilihat dari ratarata angka kelahiran total saja.

Selanjutnya menurut Subrata (1995), ukuran fertilitas dapat dihitung dengan memperhatikan pengaruh pemakaian alat kontrasepsi dan efektifitasnya terhadap pencapaian $C B R$ dan TFR melalui suatu model matematik. Dalam hal ini untuk menghitung CBR, data yang dingunakan adalah persentase KB aktif terhadap Pasangan Usia Subur (PUS), pertumbuhan PUS dan efektifitas kontrasepsi rata-rata tertimbang. Dalam model ini, ukuran fertilitas ditentukan dengan memperkirakan pengaruh pemakaian alat kontrasepsi oleh pasangan usia subur terhadap angka kelahiran. Oleh karena itu dalam perhitungannya perlu diperhatikan pertumbuhan pasangan usia subur (PUS) yang dalam perkiraan ini menggunakan perioda waktu antara.

Adapun ukuran proyeksi fertilitas berupa angka kelahiran kasar $(C B R)$ berdasarkan data persentase KB aktif terhadap $P U S$, efektifitas kontrasepsi tertimbang dan pertumbuhan $P U S$, menurut Azizah N (2015) dalam model ini CBR pada waktu $t$ dapat dihitung oleh

$$
C B R_{t}=C B R_{0}-\frac{0,5 E X_{(t-1)}}{1+v}
$$

dengan $X_{(t-1)}$ persentase peserta KB aktif terhadap PUS untuk tahun $t-1$, dan $C B R_{0}$ adalah $C B R$ sebelumnya atau $C B R$ yang ditetapkan. Sedangkan efektifitas kontrasepsi $(E)$ merupakan perkalian antara persentase peserta KB aktif dari tiap-tiap alat kontrasepsi berdasarkan kriteria efektifitasnya dengan angka efektifitas kontrasepsi yang bersangkutan, yang selanjutnya disebut efektifitas kontrasepsi tertimbang. Kemudian dihitung jumlah kelahiran dan jumlah kelahiran yang dapat dicegah untuk kurun waktu tertentu pada suatu wilayah berdasarkan perssamaan matematika (1). Sedangkan $v$ adalah laju pertumbuhan PUS.

Berbeda dengan asumsi pertumbuhan PUS eksponensial yang selama ini digunakan dalam perhitungan angka fertilitas, untuk menghitung pertumbuhan PUS $(v)$, dalam asumsi logistik, laju pertumbuhan PUS akan terbatas. Dengan asumsi tersebut, jumlah populasi dengan model ini akan selalu terbatas pada suatu nilai tertentu. Model logistik digunakan karena pada kenyataan di alam bahwa besar kecilnya populasi bergantung pada kerapatannya, sehingga laju kelahiran dan laju kematian tidak konstan (Haberman, 1977). Adapun model pertumbuhan logistik adalah sebagai berikut

$$
N(t)=\frac{a / b}{1+\left(\frac{a}{b N_{0}}-1\right) e^{-a t}}
$$

Dimana : $a / b$ merupakan ukuran populasi maksimum

No $=$ Jumlah populasi tahun awal

$N(t)=$ Jumlah populasi tahun ke $t$

Dari persamaan (2) diperoleh laju pertumbuhannya sebagai berikut 


$$
a=-\ln \left(\frac{N_{0}\left(N_{2-} N_{1}\right)}{N_{2}\left(N_{1-}-N_{0}\right)}\right)
$$

Dalam hal ini $a=v$, dengan $N_{0}, N_{l}, N_{2}$ ditentukan dari data jumlah PUS untuk tiga tahun pertama atau tiga tahun terkahir atau juga dapat ditentukan dari tiga tahun pertama waktu antara. Setelah memperoleh angka perkiraan kelahiran kasar (CBR), maka dapat dihitung angka kelahiran total (TFR) dengan menggunakan persamaan (4) sebagai berikut

$$
T F R_{t}=14 C B R_{t}
$$

Menurut Subrata (1995), penggunaan alat kontrasepsi akan sangat berpengaruh kepada angka kelahiran. Sebagai dampak dari penggunaan KB yaitu akan ada kelahiran yang tidak mungkin terjadi atau kelahiran tercegah yang dimodelkan sebagai berikut

$$
P B R_{t}=\frac{C B R_{0}-C B R_{t}}{1000} P_{t}
$$

Dalam hal ini, $P B R_{t}$ adalah angka kelahiran tercegah tahun akhir, sedangkan $C B R_{0}$ adalah angka kelahiran kasar tahun awal, $C B R_{t}$ adalah angka kelahiran kasar proyeksi tahun akhir, dan $P_{t}$ adalah penduduk tahun $t$. Selanjutnya angka kelahiran tercegah dapat juga digunakan untuk menghitung angka kelahiran tanpa KB berdasarkan jumlah kelahiran dan jumlah penduduk (populasi) di suatu wilayah yaitu

$$
B R W C_{t}=C B R_{t} P_{t}
$$

Dimana $B R W C_{t}$ adalah angka kelahiran tanpa KB tahun $t$. Kemudian untuk mengetahui angka kelahiran yang mungkin terjadi pada tahun $t$ digunakan rumus sebagai berikut

$$
B M O_{t}=B R W C_{t}-P B R_{t}
$$

Dengan $B M O_{t}$ adalah angka kelahiran yang mungkin terjadi tahun $t$

\section{Hasil dan Pembahasan}

Fertilitas adalah kemampuan alami untuk memberikan keturunan dari pasangan usia subur (PUS). Pasangan usia subur berkisar antara usia 15-49 tahun dimana pasangan (laki-laki dan perempuan) sudah cukup matang dalam segala hal terlebih organ reproduksinya sudah berfungsi dengan baik (Kamus BKKBN). Adapun data jumlah PUS provinsi Jawa Barat kurun waktu lima tahun dari 2010 sampai dengan 2015 dapat dilihat pada tabel 1 berikut

Tabel 1. PUS Provinsi Jawa Barat

\begin{tabular}{|c|c|}
\hline Tahun & Jumlah PUS \\
\hline $\mathbf{2 0 1 0}$ & 23.687 .205 \\
\hline $\mathbf{2 0 1 1}$ & 24.209 .863 \\
\hline $\mathbf{2 0 1 2}$ & 24.586 .863 \\
\hline $\mathbf{2 0 1 3}$ & 24.846 .042 \\
\hline $\mathbf{2 0 1 4}$ & 25.193 .861 \\
\hline $\mathbf{2 0 1 5}$ & 25.420 .808 \\
\hline
\end{tabular}

Sumber: SUSENAS tahun $(2010-2015)$ 
Laju pertumbuhan PUS provinsi Jawa Barat dalam kurun waktu lima tahun tersebut bersifat logistik (Azizah N, Gunawan G; 2015), karena adanya faktor yang mempengaruhi laju pertumbuhannya yang tidak terus menerus bertambah secara cepat. Oleh karena itu, dengan menggunakan asumsi tersebut, maka laju pertumbuhan provinsi Jawa Barat berdasarkan persamaan (4) adalah sebesar 36,39 \% per tahun. Dengan diketahuinya laju pertumbuhan PUS, selanjutnya dapat ditentukan proyeksi jumlah PUS provinsi Jawa Barat untuk tahun 2016, yaitu sebesar 25.274.291 orang pasangan usia subur.

Dalam menjalani kehidupan berkeluarga, PUS sangat mudah dalam memperoleh keturunan, dikarenakan keadaan kedua pasangan tersebut normal. Oleh karenanya bagi PUS perlu melakukan pengaturan fertilitas, perawatan kehamilan dan persalinan aman. Salah satu cara yang dapat mengatur hal tersebut adalah dengan melakukan kontrasepsi. Kontrasepsi merupakan suatu cara atau metode yang bertujuan untuk mencegah pembuahan sehingga tidak terjadi kehamilan (Kamus BKKBN).

Macam-macam alat kontrasepsi yang banyak digunakan oleh masyarakat saat ini yaitu IUD (Intra Uterine Device), Kondom, KB Suntik, pil KB, Implant, MO (Metode Operasi). Jenis kontrasepsi yang dipakai oleh pasangan usia subur mempunyai pengaruh terhadap besar kecilnya dampak pada angka kelahiran. Hal ini disebabkan setiap jenis alat kontrasepsi mempunyai daya lindung terhadap kemungkinan terjadinya kehamilan. Tingkat efektivitas alat kontrasepsi ditentukan berdasarkan tingkat kemampuan alat kontrasepsi yang bersangkutan dapat melindungi kemungkinan terjadinya kehamilan berdasarkan uji laboratorium dan tingkat kedisiplinan pemakainya. Penggunaan alat kontrasepsi dalam arti efektivitas klinik, yaitu pengaruh suatu cara kontrasepsi untuk mencegah kehamilan (Subrata, 1995). Efektifitas untuk masing-masing alat kontrasepsi yang dipakai adalah efektivitas dengan kategori tinggi, sedang dan rendah, seperti yang disajikan dalam tabel berikut

Tabel 2 Efektivitas Tiap-tiap Alat Kontrasepsi

\begin{tabular}{|c|c|c|c|}
\hline & Tinggi (\%) & Sedang (\%) & Rendah (\%) \\
\hline MO & 100 & 100 & 100 \\
\hline IUD & 95 & 90 & 85 \\
\hline Implant & 95 & 95 & 85 \\
\hline Pil KB & 95 & 87 & 70 \\
\hline KB Suntik & 95 & 87 & 70 \\
\hline Kondom & 95 & 85 & 80 \\
\hline
\end{tabular}

Sumber: hasil pencatatan dan pelaporan BKKBN yang dapat diasumsikan menurut tingkat tinggi, sedang dan rendah (United Nation)

Terlihat dari tabel 2 tersebut bahwa jika cara penggunaan alat kontrasepsi benar (tinggi), maka kemungkinan tercegahnya kehamilan sangat tinggi, jika penggunaan kontrasepsi kurang tepat (sedang) maka kemungkinan tercegahnya kehamilan sedang, dan jika penggunaan kontrasepsi tidak tepat (rendah) maka tercegahnya kehamilan akan rendah. Untuk mendapatkan nilai mix efektivitas kontrasepsi dari alat kontrasepsi dapat dihitung dengan cara menjumlahkan tiap-tiap persentase penggunaan alat kontrasepsi dengan persentase efektivitas tiap-tiap alat kontrasepsinya adalah sebagai berikut

mix Efektivitas Tinggi

$E=(\% M O \times 1)+(\% I U D \times 0,95)+(\%$ Implan $\times 0,95)+(\%$ Pil $\times 0,95)+(\%$ suntikan $\times 0,95)+$ (\%Kondom $\times 0,95)$

mix Efektivitas Sedang $E=(\% M O \times 1)+(\% I U D \times 0,90)+(\%$ Implan $\times 0,95)+(\%$ Pil $\times 0,87)+(\%$ suntikan $\times 0,87)+$ $(\%$ Kondom $x 0,85)$ 
mix Efektivitas Rendah

$E=(\% M O \times 1)+(\%$ IUD $\times 0,85)+(\%$ Implan $\times 0,85)+(\%$ Pil $\times 0,70)+(\%$ suntikan $\times 0,70)+$ $(\%$ Kondom $x 0,80)$

Mix efektivitas kontrasepsi tersebut dapat digunakan untuk menghitung angka kelahiran kasar (CBR), yang mana laju pertumbuhan PUS penduduk harus diketahui terlebih dahulu. Laju pertumbuhan PUS penduduk adalah perubahan jumlah PUS penduduk di suatu wilayah tertentu setiap tahunnya. Kegunaannya adalah memprediksi jumlah PUS penduduk di suatu wilayah di masa yang akan datang. Dalam hal ini prediksi laju PUS penduduk provinsi Jawa Barat untuk tahun 2016 berdasarkan perhitungan persamaan (3) adalah 36,39\% per tahun.

Menurut catatan, persentase jumlah pengguna alat kontrasepsi MO, IUD, implant, pil, suntikan dan kondom pada tahun 2010 di provinsi Jawa Barat berturut-turut adalah 1,55\%; 5,22\%; 1,94\%; $16,55 \%$; 37,51\%; dan 0,1\% (SUSENAS, 2010). Maka mix efektifitas penggunaan kontrasepsi tinggi, sedang, dan rendah masing-masing adalah, 0,598; 0,552; dan 0,456. Dari hasil tersebut terlihat bahwa semakin tinggi efektifitas penggunaan alat kontrasepsi maka semakin besar pula keberhasilan program KB dan semakin tinggi pula tercegahnya kehamilan.

Berdasarkan survey BPS tahun 2010 diketahui bahwa CBR $_{0}$ adalah 17,40 dan TFR $_{0}$ adalah 2,34 dengan rasio jumlah peserta KB aktif terhadap PUS adalah 0,65. Sehingga berdasarkan hasil perhitungan persentase mix efektifitas di atas dan dengan menggunakan laju petumbuhan PUS 36,39\% per tahun, maka perkiraan angka kelahiran kasar (CBR) untuk tahun 2016 dapat ditentukan beradasrkan persamaan (2). Hasilnya diperoleh bahwa CBR dengan tingkat efektifitas kontrasepsi tinggi, sedang, dan rendah masing-masing adalah 17.258; 17.269; dan 17.292 orang yang lahir. Setelah diperoleh hasil tersebut, maka dapat dihitung angka kelahiran total (TFR) dengan menggunakan persmaan Soetedjo-Sahala, yaitu $T F R_{t}=14 C B R_{t}$. Oleh karena itu perkiraan TFR tahun 2016 dengan kriteria efektifitas kontrasepsi tinggi, sedang, dan rendah masing-masing adalah 2,416; 2418; dan 2,421. Hal ini berarti bahwa wanita yang berusia 15-49 pada PUS rata-rata mempunyai anak tidak lebih dari 2 anak selama usia suburnya jika dipengaruhi oleh penggunaan alat kontrasepsi.

Selanjutnya dengan menggunakan persamaan (3), proyeksi penduduk provinsi Jawa Barat tahun 2016 adalah 46.583.074 maka perkiraan angka tercegah tahun 2016 dapat ditentukan menurut persamaan berikut

$$
P B R_{t}=\frac{C B R_{0}-C B R_{t}}{1000} P_{t}
$$

dengan $P B R_{t}$ adalah angka kelahiran tercegah tahun $t$ dan $P_{t}$ jumlah penduduk tahun $t$, Sehingga didapat proyeksi persentase angka kelahiran tercegah menurut kriteria efektifitas kontrasepsi tinggi, sedang, dan rendah masing-masing adalah $6.603 ; 6.094 ; 5.030$

Berdasarkan jumlah kelahiran dan jumlah penduduk di suatu wialayah, $C B R$ dapat juga digunakan untuk menghitung angka kelahiran tanpa KB. Jika $C B R_{2016}$ dengan asumsi logistik adalah 17.228 dan proyeksi jumlah penduduk menurut persamaan (3) adalah 46.583.074, maka kelahiran tanpa KB yang terjadi di provinsi Jawa Barat adalah 8.044.511. Sehingga dengan berdasarkan $C B R$ menurut kriteria efektifitas kontrasepsi tinggi, sedang, dan rendah maka akan diperoleh proyeksi angka kelahiran yang mungkin terjadi pada tahun 2016 masing-masing adalah 7.348.225; 7.435.077; 7.541.513.

\section{Kesimpulan}

Berdasarkan metoda perhitungan seperti yang telah diuraikan di atas, maka metoda tersebut dapat digunakan untuk menentukan proyeksi TFR pada masing-masing wilayah yang ada di provinsi Jawa Barat yang didasarkan pada efektifitas penggunaan alat kontrasepsi pada tahun 2016. Bahkan dari perhitungan dengan menggunakan metoda tersebut dapat dihitung jumlah perkiraan angka 
kelahiran tercegah untuk masih-masing wilayah yang ada di wilayah provinsi Jawa Barat, yang mana angka tersebut mengindikasikan keberhasilan program KB untuk masing-masing wilayah tersebut. Dari hasil perhitungan menunjukan bahwa semakin tinggi efektifitas penggunaan alat kontrasepsi, maka semakin tinggi pula angka kelahiran tercegah yang mengakibatkan sedikitnya angka kelahiran yang mungkin terjadi.

\section{Ucapan Terima Kasih}

Artikel ini ditulis atas dukungan biaya DIRJEN RISTEK DIKTI tahun anggaran 2017 melalui LPPM UNISBA.

\section{Referensi}

[1] Azizah Nur-Gunawan G, 2015, Perhitungan angka kelahiran tercegah, Laporan study lapangan BKKBN

[2] Brown RI, 1997, Introduction to Mathematics of Demography, Winsted: Actex Publication

[3] BPS, 2007, Survey Demography dan Kesehatan Indonesia 2007, Macro International

[4] Coale, A.J, 1971, The Growth and Structure of Human Populations. Princeton University Press, New Jersey

[5] Gunawan G, 2007, Solusi Kualitatif Pertumbulan Populasi Logistik, Tridarma

[6] Lucas D, 1984, Introduction to Demogragphy Parameters, Report-Research

[7] Mundiharno, 1998, Estimasi Metoda Tak Lansung, report survey kependudukan Jakarta

[8] Oktriani D-Gunawan G, 2015, Pengukuran Fertilitas Berdasarkan Jumlah Penduduk, Laporan study lapangan BKKBN

[9] Palmore JA, 1978, Regeression Estimates of Changes in Fertility for Major Nations and Territories. Paper of the East-West Population Institute no.58

[10] Rele JR, Fetility Analysis Through Extension of Stable Population Concepts. Barkeley: University of California

[11] Subrata M , 1995, Analisis Perkiraan Fertilitas di Indonesia Tahun 1995 Pendekatan Sutedjo-Sahala, BKKBN Jakarta

[12] Sorvianti I, 2012, Pengukuran Fettilitas Dengan Metoda Tak Langsung, IPB 